\title{
Riscos da vacinação antiinfluenza em crianças com infecção pelo HIV
}

\author{
Influenza immunization risks in HIV infected children
}

\author{
Norma Rubini*
}

$\mathbf{N}_{\mathrm{a}}$ dois fenômenos principais: a ativação imunológica e a imunodepressão. Várias manifestações clínicas da infecção pelo HIV não são decorrentes do quadro de imunodeficiência, mas sim relacionadas aos processos de replicação viral, ativação imunológica e produção excessiva de citocinas pró-inflamatórias. Dentre estas, destacam-se, na população pediátrica, a encefalopatia pelo HIV e a síndrome consumptiva (wasting syndrome). Além disso, a ativação imunológica favorece a replicação do HIV em células que estejam em estado de infecção latente e a entrada do HIV em linfócitos e monócitos/macrófagos não infectados, possibilitando um agravamento da depleção da população de linfócitos T CD4+.

As imunizações contra agentes infecciosos acarretam a ativação do sistema imune, e o seu impacto no curso virológico, imunológico e clínico de pacientes com infecção pelo HIV foi investigado em vários estudos envolvendo adultos e crianças. Teoricamente, o potencial de riscos para o paciente pediátrico, especialmente abaixo dos dois anos de idade, é maior, devido à administração de múltiplas vacinas e à imaturidade do sistema imunológico. Um outro fator agravante é o fato de que as crianças nesta faixa etária apresentam taxas de replicação viral significativamente mais elevadas do que os adultos.

Neste número do Jornal de Pediatria, Carvalho e cols. ${ }^{1}$ avaliaram os efeitos da vacinação contra o vírus influenza na taxa de replicação do HIV e na subpopulação de linfócitos T CD4+em 44 crianças infectadas pelo HIV. Os autores não observaram nenhuma alteração significativa na carga viral secundária à administração da vacina antiinfluenza. Contudo, foi constatado um decréscimo transitório significativo na contagem absoluta dos linfócitos T CD4+, sem uma redução correspondente nos valores percentuais. Estes dados indicam que, provavelmente, a depleção de linfóci-

\footnotetext{
* Profa Livre Docente em Alergia e Imunologia. Coordenadora do Curso de Pós-graduação em Alergia e Imunologia - Universidade do Rio de Janeiro - Uni-Rio.
}

tos T CD4+ observada ocorreu em função do processo de ativação imunológica, e não de um aumento da atividade viral. Foi observado, ainda, que o esquema anti-retroviral não foi modificado no período de um ano após a aplicação da vacina em $41(80,4 \%)$ pacientes, apontando para a ausência de efeitos deletérios em médio prazo no prognóstico do paciente.

Os estudos investigando o impacto da vacina antiinfluenza em pacientes pediátricos foram realizados com um número pequeno de pacientes e incluíram populações heterogêneas com relação às características virológicas, imunológicas e clínicas, bem como esquemas de terapia antiretroviral com potência variável. Os resultados destes estudos são controversos, sendo que a maioria indica um aumento transitório da replicação viral, sem observar nenhum agravamento na situação imunológica ou no prognóstico clínico dos pacientes ${ }^{2-7}$. As diferenças observadas nos resultados podem ser ocasionadas pela influência destas variáveis.

No estudo de Carvalho e cols. ${ }^{1}$, a maioria dos pacientes $(68,7 \%)$ encontrava-se em situação imunológica e clínica de graus leve a moderado, sendo que 54,3\% não apresentava nenhum déficit imunológico, e $86,3 \%$ estava em uso de terapia anti-retroviral efetiva. Portanto, os resultados do estudo permitem concluir que em crianças infectadas pelo HIV estáveis, em situação clínica e imunológica razoável e com boa resposta à terapia anti-retroviral vigente, a administração da vacina antiinfluenza parece ser segura.

Recentemente, Kolber e cols. ${ }^{8}$ investigaram a possibilidade da emergência de cepas de HIV com resistência aos medicamentos anti-retrovirais em adultos com carga viral indetectável (<200 cópias/ml) em conseqüência da elevação da carga viral secundária à vacinação anti-influenza. Foram avaliados 37 adultos, sendo que somente sete apresentaram elevação da taxa de replicação viral no período pós-vacinal. Dentre estes, foi detectada a emergência de cepas de HIV com mutações conferindo resistência a antiretrovirais em curto prazo em dois pacientes, e em médio prazo em outros dois pacientes. Os autores concluíram que 
existe o risco de surgimento de cepas de HIV resistentes à terapia anti-retroviral em um pequeno número de pacientes que apresenta elevação da carga viral pós-imunização antiinfluenza.

Os estudos avaliando o impacto da vacina contra o vírus influenza em pacientes com infecção pelo HIV não permitem, devido ao tamanho das casuísticas, identificar quais os fatores/características de risco para um possível efeito adverso da vacina no quadro virológico, imunológico, falha terapêutica e evolução clínica do paciente. É possível que os riscos da ativação imunológica em pacientes sem uma supressão viral adequada e/ou com déficit imunológico acentuado sejam muito maiores do que em pacientes estáveis.

É importante salientar que no seguimento clínico de crianças com infecção pelo HIV a interpretação de alterações na carga viral e contagem de linfócitos T CD4+ em períodos pós-vacinais deve ser cautelosa, evitando-se uma introdução precoce e/ou mudanças desnecessárias da terapia anti-retroviral nestes períodos. Idealmente, recomendase programar o monitoramento virológico e imunológico para um prazo superior a um mês pós-imunização. Além disso, reforços extras de imunizações em pacientes com infecção pelo HIV com esquema vacinal completo e atualizado não devem ser administrados, uma vez que podem resultar em riscos, sem nenhum benefício adicional.

\section{Referências bibliográficas}

1. Carvalho AP, Dutra LC, Tonelli E. Vacinação contra influenza em crianças infectadas pelo HIV: alterações imunológicas e na carga viral. J Pediatr (Rio J) 2003;79(1):29-40.

2. Yerly S, Wunderli W, Wyler CA, Kaiser L, Hirschel B, Suter S, et al. Influenza immunization of HIV-infected patients does not increase HIV-1 viral load. AIDS 1994;8:1503-4.

3. Ramilo O, Hicks PJ, Borvak J, Gross LM, Zhong D, Squires JE, et al. $\mathrm{T}$ cell activation and human immunodeficiency virus replication after influenza immunization of infected children. Pediatr Infect Dis J 1996;15:197-203.

4. Jackson CR, Vavro CL, Valentine ME, Pennington KN, Lanier ER, Katz SL, et al. Effect of influenza immunization on immunologic and virologic characteristics of pediatric patients infected with human immunodeficiency virus. Pediatr Infect Dis J 1997;16:200-4.

5. Donovan RM, Moore E, Bush CE, Markowitz NP, Saravolatz LD. Changes in plasma HIV RNA levels and CD4 cell counts after vaccination of pediatric patients. AIDS 1997;11:1013-21.

6. Vigano A, Bricalli D, Trabattoni D, Salvaggio A, Ruzzante S, Barbi $\mathrm{M}$, et al. Immunization with both $\mathrm{T}$ cell-dependent and $\mathrm{t}$ cell independent vaccines augments HIV viral load secondary to stimulation of tumor necrosis factor alpha. AIDS Res Hum Retroviruses 1998;14:727-34.

7. Keller M, Deveikis A, Cutillar-Garcia M, Gagajena A, Elkins K, Plaeger S, et al. Pneumococcal and influenza immunization and human immunodeficiency virus load in children. Pediatr Infect Dis J 2000;19:613-8.

8. Kolber MA, Gabr AH, De La Rosa A, Glock JA, Jayaweera D, Miller N, et al. Genotypic analysis of plasma HIV-1 RNA after influenza vaccination of patients with previously undetectable viral loads. AIDS 2002;16:537-42. 